University for Business and Technology in Kosovo

UBT Knowledge Center

Theses and Dissertations

Student Work

Summer 6-2020

\title{
Hulumtimi rreth llojeve të ambalazheve dhe roli i tyre në industrinë ushqimore
}

Xheneta Luma

University for Business and Technology - UBT

Follow this and additional works at: https://knowledgecenter.ubt-uni.net/etd

Part of the Food Science Commons

\section{Recommended Citation}

Luma, Xheneta, "Hulumtimi rreth llojeve të ambalazheve dhe roli i tyre në industrinë ushqimore" (2020). Theses and Dissertations. 10.

https://knowledgecenter.ubt-uni.net/etd/10

This Thesis is brought to you for free and open access by the Student Work at UBT Knowledge Center. It has been accepted for inclusion in Theses and Dissertations by an authorized administrator of UBT Knowledge Center. For more information, please contact knowledge.center@ubt-uni.net. 


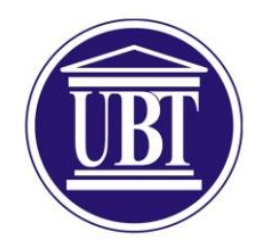

Kolegji UBT

Fakulteti: Shkencat e Ushqimit dhe Bioteknologji

Specializimi: Teknologji Ushqimore

\section{HULUMTIMI RRETH LLOJEVE TË AMBALAZHEVE DHE ROLI I TYRE NË INDUSTRINË USHQIMORE}

Shkalla Bachelor

Xheneta Luma

Qershor/ 2020

Prishtinë 


\section{UBI}

Kolegji UBT

Fakulteti:Shkencat e Ushqimit dhe Bioteknologji

Specializimi: Teknologji ushqimore

Punim Diplome

Viti akademik 2016-2017

Xheneta Luma

\section{HULUMTIMI RRETH LLOJEVE TË AMBALAZHEVE DHE ROLI I TYRE NË INDUSTRINË USHQIMORE}

Mentori: Dr.sc.Hyrije Koraqi

Qershor / 2020

Ky punim është përpiluar dhe dorëzuar në përmbushjen e kërkesave të pjesshme për Shkallën Bachelor 


\section{ABSTRAKT}

Sot, ambalazhimi i ushqimit është pranuar si një strategji për rritjen e konkurrencës së produkteve ushqimore nga ekspertët. Ambalazhimi i ushqimit është mbyllja e ushqimit për ta mbrojtur atë nga dëmtimi, ndotja, prishja, dëmtuesit, gjatë transportit, magazinimit dhe shitjes me pakicë. Zhvillimi i materialeve të ambalazhimit tregon zhvillimin paralel me teknologjinë. Sidomos rritja e numrit të të punësuarve, veqanërisht rritja e punësimit të femërave gjithnjë e më shumë e rriti kërkesën për ushqim të gatshëm. Rritja e kërkesës për ushqim të përgatitur lehtësisht solli teknologjinë e re të ambalazhimit dhe funksionimi i ambalazhimit është rritur. Prodhimi i ambalazheve për

konfeksionimin e produkteve ushqimorë, po i nënshtrohet presioneve të vazhdueshme të ekologjistëve sikurse dhe legjislacionit të ri, në funksion të higjienës dhe mjedisit. Nisur nga problemet e mbrojtjes së mjedisit, kursimin e burimeve natyrore dhe energjetike sikurse dhe për kushtet e veçanta që kërkohen për ambalazhimin, magazinimin e transportin e produkteve ushqimore, ekziston sot një shumëllojshmëri ambalazhesh të produkteve në qelq, letër, plastikë, tekstil, dru dhe metal. Vlerësimi i këtij problemi, ka çuar në arritjet e sotme të industrisë për prodhimin e ambalazheve tepër të sofistikuar, higjienikë dhe tërheqës për konsumatorët. Konkurrenca dhe standardet e kërkuara të ambalazheve, e bëjnë tepër të vështirë përzgjedhjen e tyre në përputhje me specifikat e produkteve të ndryshme industriale e ushqimore.

Qëllimi i këtij hulumtimi do të jetë drejtuar nga rëndësia e ambalazhimit, gjendja e ambalazhimit në Kosovë. Përkundër rëndësisë së paketimit të industrive ushqimore, ajo është mjaft anonime dhe është lënë pas dore disi në përpjekjet e kërkimit të marketingut në Kosovë. Qëllimi i këtij studimi ishte të shqyrtojë lidhjen midis ambalazhimit dhe sjelljes së konsumatorëve të produkteve ushqimore në Kosovës si dhe në qëllimin e hulumtimit duhet të zbulohet se sa janë të informuar qytetaret per ambalazhimin dhe se sa rëndesi ka ambalazhimi.

Të gjitha analizat statistikore janë punuar duke përdorur programi MS Excel. 


\section{MIR $\ddot{E N J O H J E / F A L E N D E R I M E ~}$}

Një falenderim i veçantë sigurisht shkon për udhëheqësen time profesoreshën Dr.sc.Hyrije Koraqi për ndihmën, për mbështetjen që më ofroi gjatë studimit të këtij punimi.

Falënderimi im për çdo person që kontriboi për mundësinë e arritjes së këtij qëllimi nuk do të ketë asnjëherë fund.

Falëndëroj miket e mia të dashura për mbështetjen, këshillat dhe çastet që i kemi shkëmbyer me njëra-tjetrën.

Gjithashtu dhe të gjithë profesorëve të tjerë që na dhuruan dije gjatë këtyre viteve.

Familja ime, prindër të dashur që gjithmonë jeni munduar të më udhëzoni drejt rrugës së drejtë, ju falënderoj pafundësisht për çdo gjë. Keni bërë të jem e bekuar për besimin, përkrahjen dhe edukimin që më keni ofruar në çdo hap të jetës. 


\section{PËRMBAJTJA}

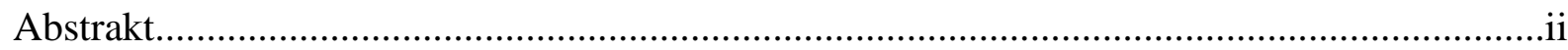

1.Hyrje

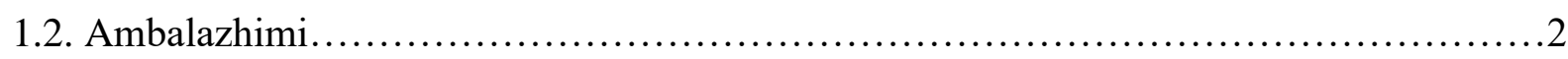

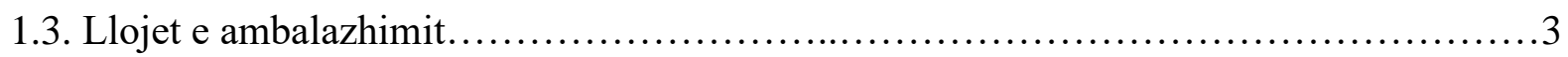

1.2.1. Materialet e përdorura për prodhimin e ambalazhit të ushqimit.......................................

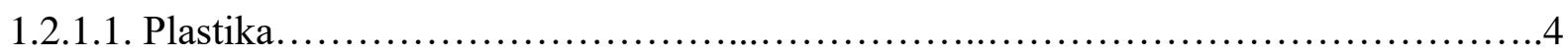

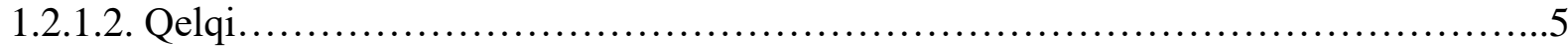

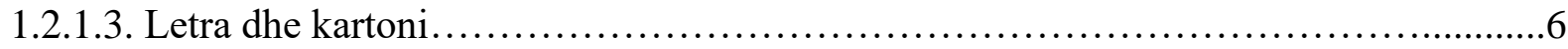

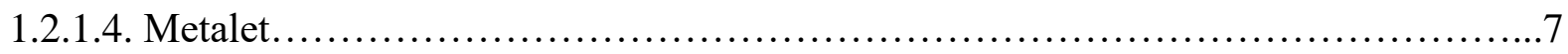

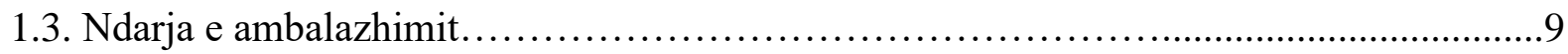

1.4. Karakteristikat e ambalazhimit..................................................... 10

1.5. Rolet kryesore të ambalazhimit..................................................... 10

1.6. Cfarë duhet të kemi parasysh para zgjedhjes së ambalazhimit?........................................11

2.Shqyrtimi i literaturës....................................................................................................13

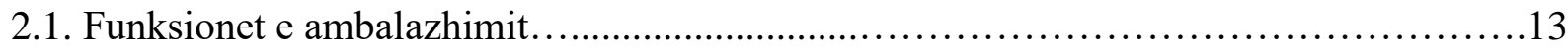

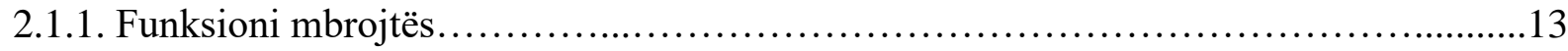

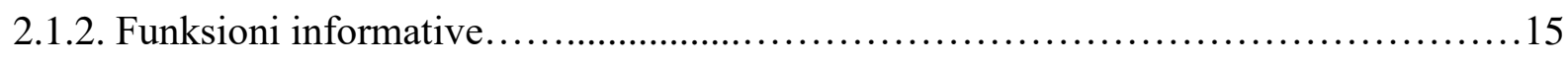

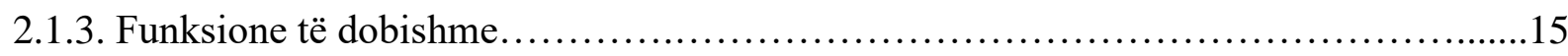

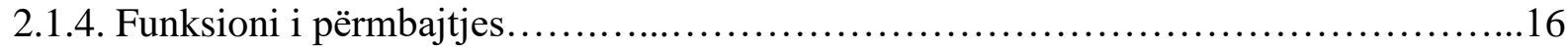

2.1.5. Funksioni i sigurisë............................................................. 16

2.1.6. Funksioni i ambalazhimit ekologik .............................................. 16

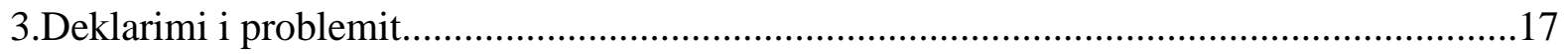

3.1. Etiketimi dhe dizajnimi iambalazhimit................................................ 17

4. Metodologjia e hulumtimit......................................................... 19

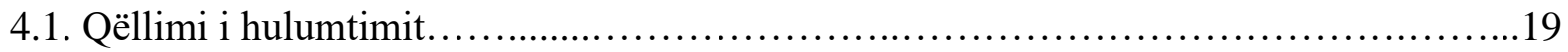

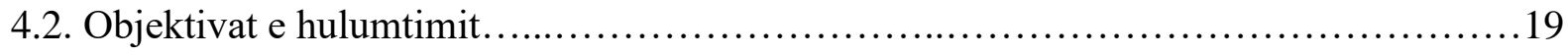

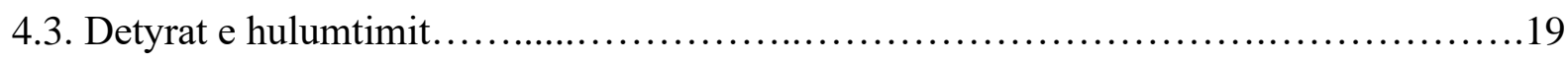


4.4. Metodat,teknikat dhe instrumentet e kërkimit(hulumtimit).. .........................20

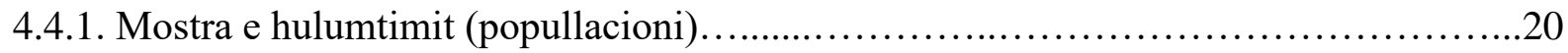

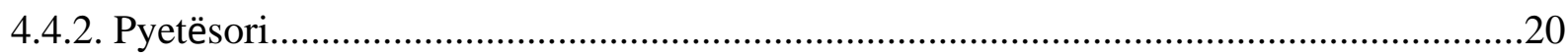

5.Prezantimi dhe analiza e rezultateteve …............................................................21

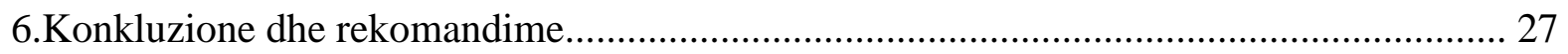

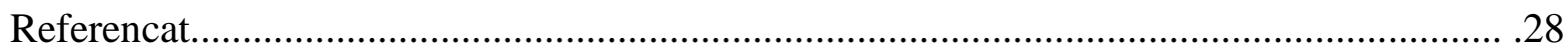




\section{LISTA E FIGURAVE}

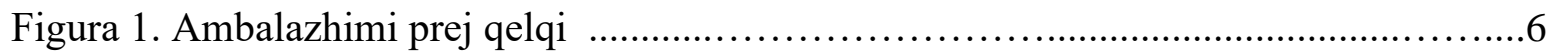

Figura 2. Ambalazhimi prej letre dhe kartoni .............................................

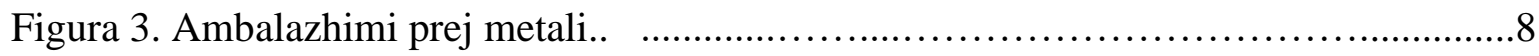

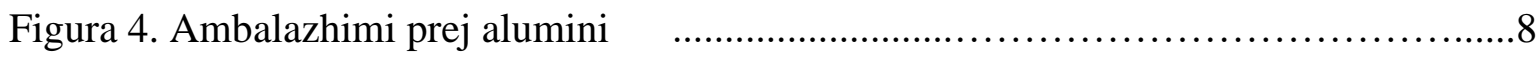

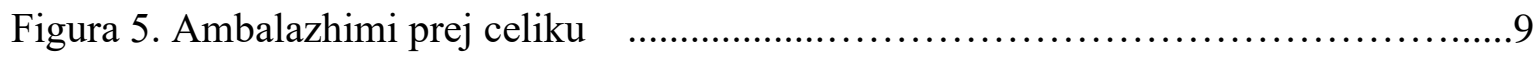

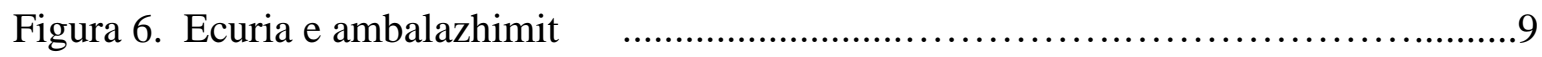




\section{LISTA E TABELAVE}

Tabela 1. Tabela perdoret për ambalazhimin e ushqimit ...................................5 


\section{HYRJE}

Sot, ambalazhimi i ushqimit është pranuar si një strategji për rritjen e konkurrencës së produkteve ushqimore nga ekspertët. Ambalazhimi i ushqimit është mbyllja e ushqimit për ta mbrojtur atë nga dëmtimi, ndotja, prishja, dëmtuesit, gjatë transportit, magazinimit dhe shitjes me pakicë. Ambalazhi etiketohet me informacione të tilla si sasia e përmbajtjes, përbërësit, përmbajtja ushqyese, udhëzimet e gatimit (nëse është e rëndësishme) dhe data e skadimit. Ambalazhi duhet të dizajnohet dhe të zgjidhet në mënyrë të tillë që të mos ketë ndërveprime të padëshiruara mes tij dhe ushqimit (Estiri et al.,2010). Llojet e ambalazhimit përfshijnë qese, shishe, kanaçe, kuti kartoni dhe tabaka. Ambalazhimi i ushqimit ështe pjesërisht art dhe pjesërisht shkencë - që të dyja janë të rëndësishme për zhvillimin e një ambalazhimi efektiv dhe efiqient ose sistemeve të paketim. Përpunimi i ushqimit është konvertimi i lëndëve (përbërësve) të para në ushqim ose në forma të tjera të gatshme për konsum, me anë të mjeteve fizike ose kimike dhe proceseve teknologjike. Përpunimi ushqimor kombinon përbërësit e ushqimit të papërpunuar për të prodhuar produkte ushqimore të tregëtueshme që mund të përgatiten lehtë dhe të ju shërbejnë konsumatorëve. Zhvillimi i materialeve të ambalazhimit tregon zhvillimin paralel me teknologjinë. Sidomos rritja e numrit të të punësuarve, veqanërisht rritja e punësimit të femërave gjithnjë e më shumë e rriti kërkesën për ushqim të gatshëm. Rritja e kërkesës për ushqim të përgatitur lehtësisht solli teknologjinë e re të amballazhimit dhe funksionimi i ambalazhimit është rritur. Shumica e materialit të amballazhimit është krijuar për t'u përdorur për një here (Eker and Içöz 2016). Teknologjia e ambalazhimit të Ushqimit, kërkohet për të siguruar furnizim të sigurtë të produkteve ushqimore në gjendje të shëndetshme dhe me kosto minimale për nevojat e konsumatorit. Thjeshtë, ambalazhimi mban avantazhet e rujtjes së ushqimit pas përfundimit të procesit të përpunimit të tij, duke bërë të mundur që ushqimet të udhëtojnë në mënyrë të sigurtë për distanca të gjata nga pika e tyre e origjinës dhe të jenë ende të shëndetshëm në kohën e konsumimit (Robertson,2010). Ambalazhimi është një element thelbësor i përgjigjes për të adresuar sfidat kryesore të konsumit të qëndrueshëm të ushqimit në skenën ndërkombëtare, e cila ka të qartë në lidhje me minimizimin e gjurmës mjedisore të ushqimit të ambalazhuar. Një ambalazhim inovativ i qëndrueshëm synon të adresojë mbeturinat e ushqimit dhe uljen e humbjeve duke ruajtur cilësinë e ushqimit, si dhe çështjet e sigurisë së ushqimit duke parandaluar sëmundjet që sjellin ushqimin dhe ndotjen kimike të ushqimit (Guillard et al.,2018). 


\subsection{AMBALAZHIMI}

Vështirësia në përcaktimin e përkufizimin e ambalazhit vjen si rezultat i shumë faktorëve që ndikojn drejtpërdrejt në teknologjinë e prodhimit të tijë. Duke ju referuar standarteve industriale për sa i përket përkufizimit për ambalazhimin është përcaktuar si një teknikë për të përdorur materiale si mbajtës të përshtatshëm për ushqimin me qëllim mbrojtjen dhe ruajtjen e cilësisë së tij gjatë transportit e magazinimit deri në duart e konsumatorit.

Abalazhimi i ushqimit është mbyllja e ushqimit për ta mbrojtur atë nga dëmtimi, ndotja, prishja, dëmtuesit, gjatë transportit, magazinimit dhe shitjes me pakicë. Ambalazhi shpesh etiketohet me informacione të tilla si sasia e përmbajtjes, përbërësit, përmbajtja ushqyese, udhëzimet e gatimit (nëse është e rëndësishme) dhe data e skadimit. Ambalazhi duhet të dizajnohet dhe të zgjidhet në mënyrë të tillë që të mos ketë ndërveprime të padëshiruara mes tij dhe ushqimit. Llojet e ambalazhimit përfshijnë qese, shishe, kanaçe, kuti kartoni dhe tabaka. Ambalazhimi i ushqimit ështe pjesërisht art dhe pjesërisht shkencë - që të dyja janë të rëndësishme për zhvillimin e një ambalazhimi efektiv dhe efiqient ose sistemeve të ambalazhimit (Rijk and Veraart,2007).

Teknologjia e ambalazhimit të Ushqimit, kërkohet për të siguruar furnizim të sigurtë të produkteve ushqimore në gjendje të shëndetshme dhe me kosto minimale për nevojat e konsumatorit. Thjeshtë, ambalazhimi mbanë avantazhet e rujtjes së ushqimit pas përfundimit të procesit të përpunimit të tij, duke bërë të mundur që ushqimet të udhëtojnë në mënyrë të sigurtë për distanca të gjata nga pika e tyre e origjinës dhe të jenë ende të shëndetshëm në kohën e konsumimit.Tregu i ushqimit në botë po rritet në mënyrë të vazhdueshme, bashkë me të edhe nevoja për ambalazhim. Ushqimi mund të tregtohet në formë të freskët, të grirë dhe të përpunuar, por në çdo rast duhet të jetë e ambalazhuar mirë. Ushqimi dhe ambalazhimi janë përbërës të produkti ushqimor që kontribuojn në cilësinë e tij të përgjithshme për të përmbushur nevojat e konsumatorit (Robertson,2010). Ambalazhimi duhet ti plotësoj disa funksione të ndryshme:

Mbrojtja dhe ruajtja e produkteve ushqimore- Ambalazhimi duhet të mbrojë produktet ushqimore nga dëmtimet e ndryshme mekanike dhe kimike të shkaktuara nga agjentët të ndryshëm gjatë ruajtjes ,shpërndrajes dhe përdorimit.

Komunikimi midis prodhuesit dhe konsumatorit -Të gjitha ambalazhimet duhet që të informojnë jo vetëm për përmbajtjen e ingredientëve të ushqimeve që ato përmbajnë, por edhe të ndihmojn në shitjen e tyre. Dizajni i produktit të ambalazhuar krijon komunikim me konsumatorin dhe ndikon ne vendim për blerje të produkti. 
Përshtatshmëria/prakticiteti- Një ambalazh përkufizohet si I përshtatshëm kur ai mundë të hapet (të hapet dhe të mbyllet sa herë që është e nevojshme), ruhet dhe paspërdorimit të ushqimit në të, mundë të riciklohet lehtësisht.

Mbrojtja fizike- Produktet e mbyllura në pako, mund të kërkojnë mbrojtje nga faktorët e jashtëm si: shoku mekanik, dridhjet e shkaktuara, shkarkimi elektrostatik, temperatura etj.

Mbrojtja ndaj barrierave - Një pengesë apo barrierë për oksigjenin, avujt e ujit, dhe pluhurin është gjithmonë e nevojshme. Disa nga ambalazhimet përmbajnë absorbues të oksigjenit të cilat zgjasin jetën e produktit në raft. Mbajtja pastër e përmbajtjes, freskët, sterile dhe e sigurt, është funksion primar në arritjen e jetëgjatësisë se produktit në raft.

Kontrollimi- Objektet e vogla janë të bashkuara në një ambalazhim për arsye të efikasitetit. Shembull mund të kemi, produktet vendore të cilat kërkojmë qe doemos të shiten së bashku, duhet te kenë një ambalazhim të veçantë me qellim që të kërkoj më pak trajtim në paketim.

Transmetimi i informacionit- Ambalazhim dhe etiketimi mund të përdoren si komunikues i mirë i përdorimit të produktit, transportit, riciklimit dhe si duhet të behet hedhja e paketës. Shumica e artikujve përfshijnë numrat e tyre serik në ambalazhim, dhe në rastin e produkteve ushqimore (vendore), ato duhet të përmbajnë një datë skadimi.

Marketingu- Ambalazhimi dhe etiketimi përdoren gjithashtu nga shitësit me qëllim të inkurajimit të blerësve potencial në blerjen e produktit. Komunikimet e marketingut shërbejnë si dizajn i reflektimit të mesazhit të brendit dhe identitetit.

Siguria- Ambalazhim mund të luaj një rol të rëndësishëm në reduktimin e rreziqeve të sigurisë së dërgesës. Ambalazhimi mundëson reduktimin e ngatërrimeve të mundshme me konkurrues tjerë në treg.

Komoditeti- Ambalazhimi mund të këtë karakteristika të cilat rrisin besueshmërinë në shpërndarjen, trajtimin, prezantimin, shitjen, hapjen, mbylljen, përdorimin, ripërdorimin, riciklimin si dhe lehtësinë e përdorimit (Muhamedbegoviç et al.,2015).

\subsection{LLOJET E AMBALAZHIMIT}

Zbatimi i detyrimeve ligjore që lidhen me mbrojtjen e higjienës së produkteve në momentin e ambalazhimit si: pasterizimi, sterilizimi, irradiacioni etj., i ambalazheve sikurse dhe detyrime të tjera ligjore për prodhimin e përdorimin e tyre në përputhje me direktivat e BE-së për marketingun, riciklimin dhe ripërdorimin. Ambalazhet duhet të jenë lehtësisht të identifikueshme, të 
manovrueshme, të markueshëm e të etiketueshëm, të hapen kollaj, të kenë volume të përshtatshme përdorimi dhe etikë në paraqitje. Sipas përdorimit të tyre ushqimor, të jenë rezistentë ndaj temperaturës së ambientit, mikrovalëve, furnelës së thjeshtë apo ndaj depërtimit të ajrit dhe lagështisë. Kështu, nëse oksidimi i yndyrërave është faktor kufizues në konservimin e produkteve ushqimore, duhet përzgjedhur një ambalazh hermetik ndaj oksigjenit. Nëse ambalazhimi i pijeve freskuese të gazuara kërkon rezistencë ndaj depërtimit të anhidritit karbonik për të ruajtur karakterin gazues të tij, duhet përdorur material konfeksionues i papërshkueshëm ndaj tij dhe po kështu për çdo faktor specifik të konservimit të secilit produkt ushqimor.Për të minimizuar humbjet gjatë kohës së transportit e gjatë magazinimit të tyre, duhen plotësuar standarde sa më të larta në cilësi dhe në afate skadence. Sigurisht që konfeksionimi i produkteve ushqimore, sipas specifikës së tyre, rrit koston e prodhimit dhe në çdo rast duhet vlerësuar ekonomikisht konkurrenca e tyre me produktet e konfeksionuara të tregut.

\subsubsection{MATERIALET E PËRdORURA PËR PRODHIMIN E AMBALAZHIMIT TË USHQIMIT JANË:}

- Plastikë;

- Qelq;

- Kartoni , letra;

- Metalet ;

- Të tjera; Sipas kohëzgjatjes:

- Të kthyeshme

- Të pakthyeshme

\subsubsection{PLASTIKA}

Materialet plastike janë përdorur gjerësisht për ambalazhimin e ushqimit, sepse janë të lehta për tu derdhur në kallëpe dhe për të formuar folie, forma dhe struktura te ndryshme të paketimit. Ato janë përgjithësisht inerte, edhe pse jo domosdodshmërisht të pa depërtueshme .

Kanë çmim të ulët dhe janë të lehta, dhe lejojnë një zgjedhje të gjerë në aspektin e trasnparencës, ngjyrës, ngjitjes, forcës, rezistencës dhe barrierës.

Plastikat përdoren për ambalazhimin e ushqimit si: 
- Shishe dhe kontinjerë të ngurtë;

- Kavanozave, gota, gypa;

- Filma plastikë fleksibël në formë të çeseve dhe folieve;

- Shtresa në materialet shumështresore dhe të kombinuara;

- Plastikë shkumë ,kapakë plastike, shiritë plastikë;

- Filma të përdorur për etiketa të ndryshme;

Plastika si ambalazhim fleksibël përdoret mbi 90\%, dhe si ambalazhim i ngurtë rreth $17 \%$.

Për shkak të vetive të saj plastika zëvendëson metalin, qelqin dhe drurin.

Shumica e materialeve plastike janë të depërtueshme ndaj drtës dhe vështirë të depërtueshme për gazrat.

Ndryshimet kimike nën ndikimin e faktorëve klimatik shkatojnë vjetërimin e ambalazhimit i cili është një proces oksidimi qëshkakton humbje të vetive të mira fizike dhe mekanike

Nga askpekti ekologjik i degradimit natyror të këtyre materialeve, kjo veti është një faktor i rëndësishëm.

Asortimenti i ambalazhimeve plastike është mjaftë i gjerë. Për ambalazhimin e ushqimit zakonisht përdoren materialet (Tabela 1.):

Tabela 1.Llojet e materialeve që përdoren për ambalazhimin e ushqimit

\begin{tabular}{|c|c|c|c|c|}
\hline PET & Polietilen tereftalat & & & \\
\hline PE & Polietilen & PA & Poliamid & \\
\hline PP & Polipropilen & EVA & Acetat etilen vinil & \\
\hline PVC & Polivinilklorid & EVOH & alkool etilen vinil & \\
\hline LDPE & $\begin{array}{l}\text { Polietilen me densitet të } \\
\text { ulett }\end{array}$ & PS & Polistiren & \\
\hline HDPE & $\begin{array}{l}\text { Polietilen me densitet të } \\
\text { lartë }\end{array}$ & ABS & $\begin{array}{l}\text { akrilonitrile butodiene } \\
\text { stirenit }\end{array}$ & पOPE \\
\hline PC & Polikarbonat & San & Acrylonitril stireni & \\
\hline
\end{tabular}

\subsubsection{QELQI}

Ambalazhimi nga qelqi është një ambalazhim i fortë. Dy format kryesore të ambalazhimeve nga qelqi janë shishet me ngrykë të ngushtë dhe kavanozat që kanë një hapje të gjerë. Në ambalazh qelqi mund të ambalazhohen pothuajse të gjitha ushqimet në formë pluhuri, kokrra e deri te ushqimet e lëngshme nga të cilat ato të gazuara dhe nën presion. 
Vetitë e ambalazhimit nga qelqi janë: transparenca, padepërtueshmëria, inertësia, rezistenca kimike, cilësia e sipëfaqes, dizajnimi i formës, hapja e lehtë, evidentimi temper, fortësia, higjiena, ekologjikisht e pranueshme.

Qelqi ka disa të meta. Pesha e qelqit rrit kostot e transportit. Të metat e tjera janë thyerja dhe ndjeshmëria e plasaritjes nën ndikimin e presionit të bredshëm, goditjes ose goditjes termike.

Vetitë pozitive të qelqit janë qelqi është transparent por mundë të ngjyroset në varësi të destiancionit të ambalazhimit,është kimikisht inert ndaj përbërsëve të ushqimeve dhe kontaminantëve të jashtëm është rezistent ndaj shtypjes.
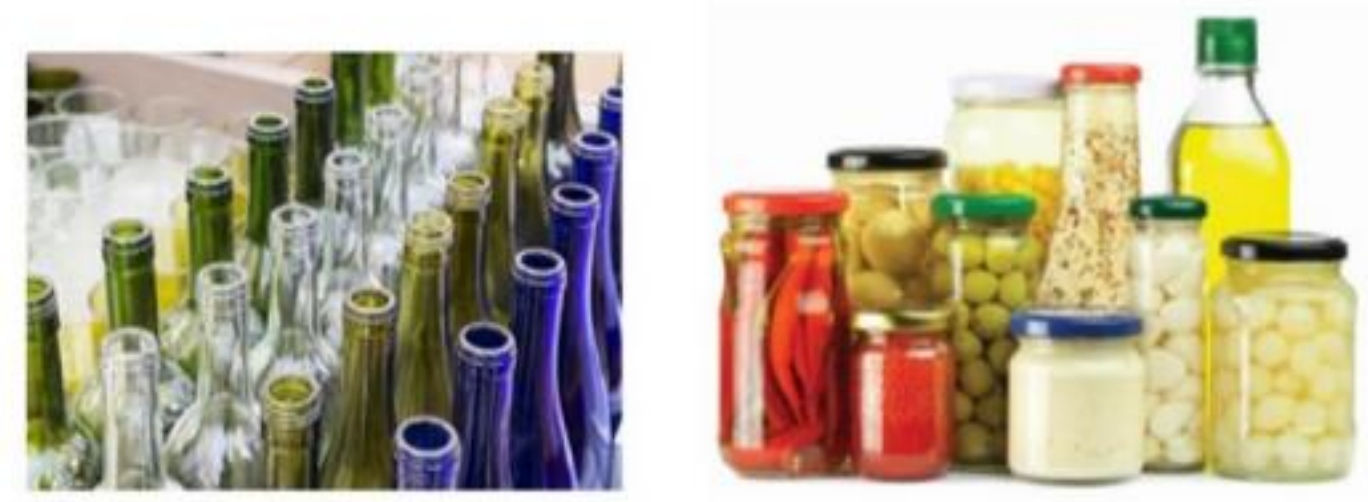

Figura 1. Ambalazhimi prej qelqi

\subsubsection{LETRA DHE KARTONI}

Materialet prej letre dhe kartoni janë përdorur gjerësisht për ambalazhimin e ushqimeve të tipit "të ngurtë e të thatë”, që kombinohen me plastika e alumin, për ambalazhe të cilat përdoren për produkte të lengshme. I tillë është ambalazhimi TETRA PAK nga katër shtresat e tij që përbëhet nga kartoni

Letra përbën rreth $39 \%$ të numrit të ambalazheve. Disa nga avantazhet e ofruara nga letra janë:

Letra mundë të prodhohet në cilësi të ndryshme dhe të marrë lehtësisht forma të ndryshme. Letra është e papërshkueshme ndaj dritës, ka veti të mira mekanike dhe është e përshtatshme për shtypjen.

Kur përdoret si ambalazhim ne kontakt me ushqimin, letra gjithmonë mveshet apo laminohet me dyll, rëshirë ose llak, me fletë plastike ose alumini për të përmirësuar vetitë e ndryshme.Ruan karkateristikat e saj për një kufijë të gjërë të ndryshimit të temperaturës. Letra është e riciklueshme. 
Kartonat kanë pëbërje të ngjajshme si letra, poë ata janë më pak të dendura dhe kane forcë më të mirë. Ato janë më të trasha se letra, peshojnë më rëndë dhe të bëra në shtresa te shumëfishta. Ambalazhimi i kartonit përdoret gjerësisht për ambalazhimin e produkteve bujqësore, të tilla si frutat dhe perimet pas korrjes. Në industrinë e ambalazhimit të ushqimit përdoren kuti kartoni si në vijim: karton të bardhë, karton të ngurtë, shirit fibrash dhe karton me fibra.

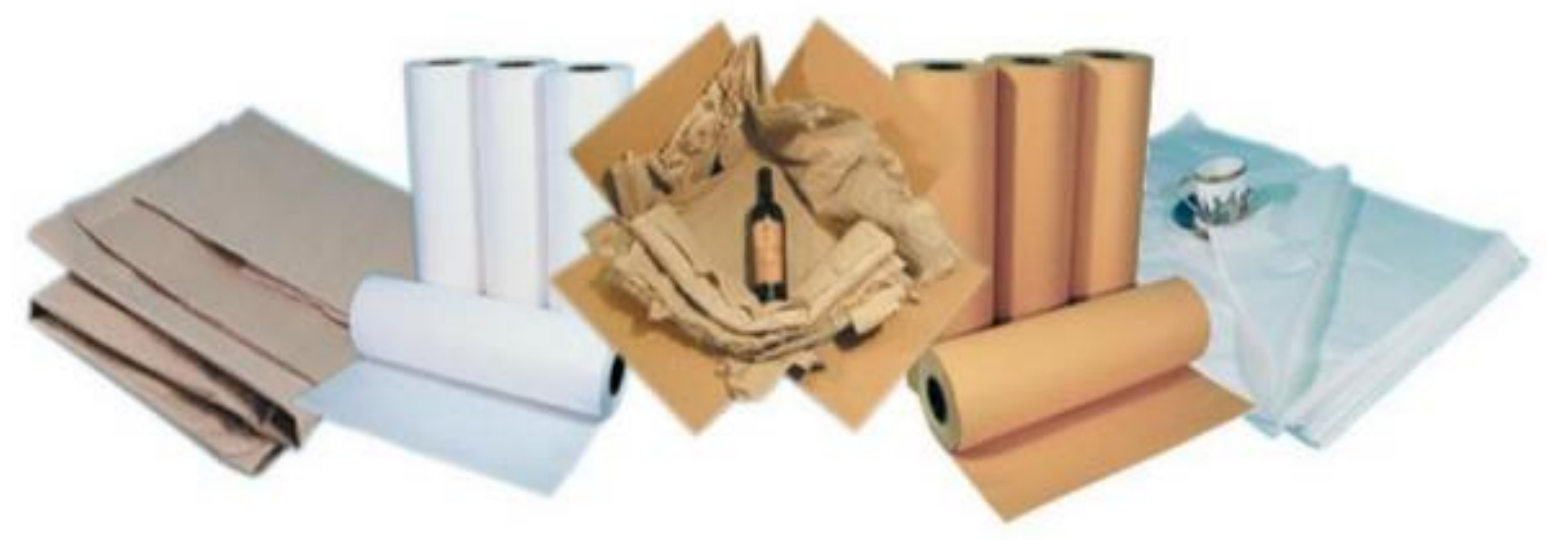

Figura 2. Ambalazhimi nga letre dhe kartoni

\subsubsection{METALET}

Metalet kanë veti të mira mekanike dhe fortësi të lartë, përdoren si ambalazhe të ushqimeve duke u siguar mbrojtje të mirë fizike ushqimeve të ambalazhuara. E përballojnë shumë mirë nxehtësinë dhe japing ngrohtësi.

Metalet reciklohen lehtësisht. Kanë toksicitet të ulët. Ambalazhimi metalik sot është një nga mabalazhimet më të rëndësishme dhe më të dëshiureshme për ambalazhimin e më shumë produkteve ushqimore dhe përdoret si kavanoza, kanaçe, kuti metalike etj.Këto ambalazhime janë të papërshkueshme ndaj lagështisë, gazrave, yndyrnave dhe dritës.Përzgjedhja e metaleve për prodhimin e ambalazhimit është e kufizuar në Al, Fe, Sn dhe Zn. 

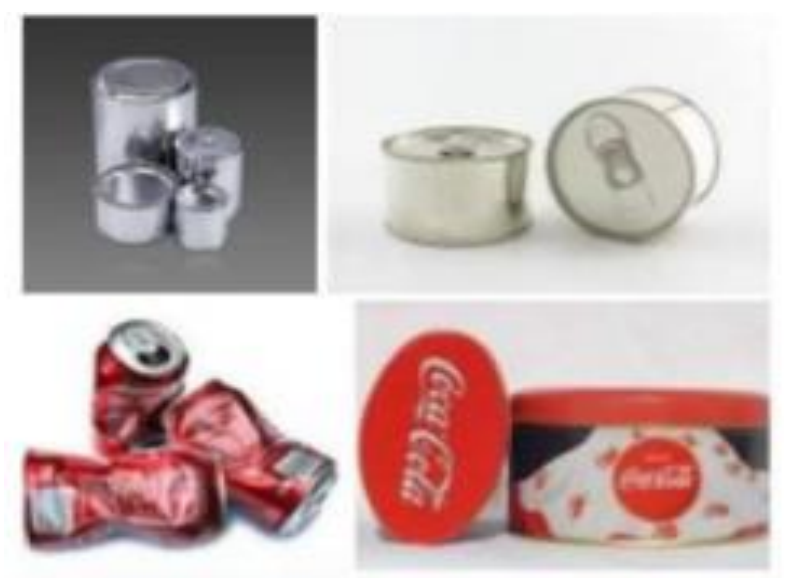

Figura 3. Ambalazhimi prej metali

Alumini- Si pjesë e ambalazheve metalike alumini ofron shumë veti të dobishme. Disa nga këto veti janë: është i lehtë, i papërshkrueshëm nga drita dhe lagështia, mundë të kombinohet me letrën ose plastikat duke dhënë ambalazhe me shumë shtresa,mundë të riciklohet etj.

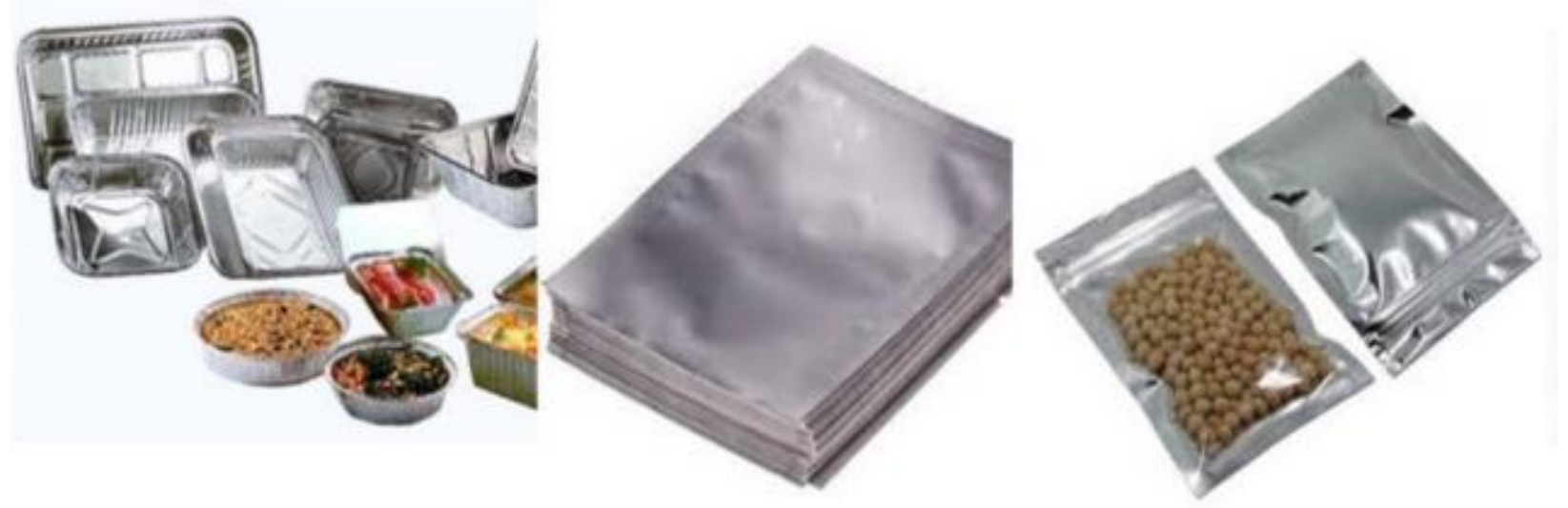

Figura 4. Ambalazhimi prej alumini

Çeliku-Sot së bashku me aluminin(ambalazhet metalike) përbëjnë rreth $21 \%$ të ambalazheve me një peshë rreth $9 \%$ ndaj peshës së përgjithëshme të tyre. Disa veqori pozitive të këtyre ambalazheve janë: Kontinierët prej qeliku janë mjaft të fortë dhe të rezistueshëm për transportimin në distanca të mëdha të produkteve të ndryshme,fabrikohen lehtësisht,mundë të duroj procese termike dhe një kufi mjaftë të gjërë temperaturash,është i papërshkrushëm ndaj dritës dhe lagështis,dhe mund të riciklohet etj. 


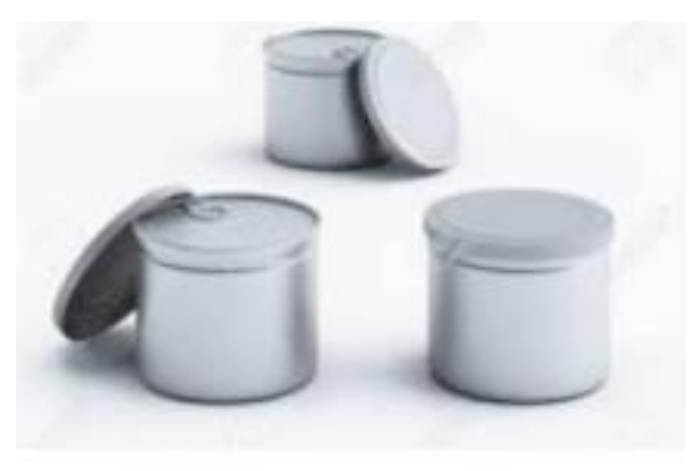

Figura 5. Ambalazhimi prej celiku

\subsection{NDARJA E AMBALAZHIMIT}

Ambalazhimet ndahen natyrshëm në tre kategori; primare, sekondare dhe terciare.

Ambalazhet primare: janë ato të cilat ndodhen në kontakt të drejtpërdrejtë me ushqimin, që kanë për funksion mbajtjen, mbrojtjen dhe lehtësimin e shpërndarjes dhe shitjes së produkteve ushqimore. Në këto paketime, materiali paketues dhe ushqimi mund të ndahen njëri me tjetrin.

Ambalazhimet sekondare: përdoren për mbrojtjen fizike të ushqimeve. Ato mbrojnë paketimet primare të ushqimeve. Mund të jenë formë-kuti në të cilat vendosen paketimet (qese plastike) ushqimore, ose disa paketime tjera primare për të lehtësuar grumbullimin, mbajtjen, transportin dhe mbrojtjen e paketimeve primare.

Ambalazhimet terciare: janë ato në të cilat vendosen paketimet sekondare, për të -lehtësuar magazinimin, transportin dhe mbrojtjen e tyre nga d;mtimet fizike, atmosferike etj, të tilla janë paletat.

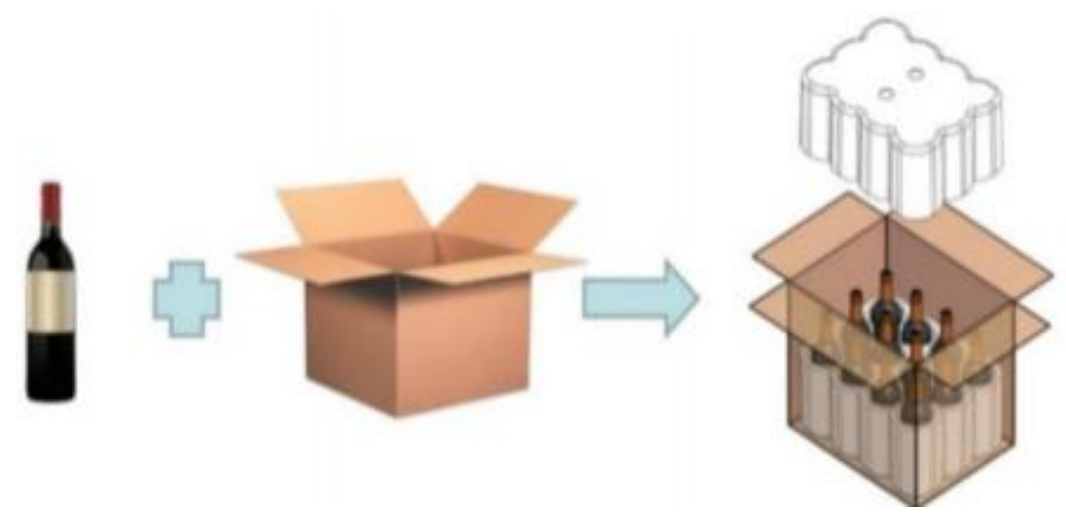

Figura 6. Ecuria e ambalazhimit 


\subsection{KARAKTERISTIKAT E AMBALAZHIMIT}

Karakteristikat fizike të ambalazhimeve:

- Dendësia e materialeve

- Përmbajtja e materialit

- Aftësia për të përballuar ekspozimin ndaj elem. të tjerë

- Frymëmarrje e materialit

- Procedura e trajtimit të materialit paketues

Karakteristikat Kimike:

- Pajtueshmëria e ushqimit me materialin paketues

Karakteristikat që duhet të bëhen të njohura për konsumatorët

- Mënyren e trajtimit të materialit

- Mbrojtjen e mjedisit

- Reduktoni materialet e ambalazhimit të përdorura

- Përdorni materialet e ambalazhimit që janë më miqësore me mjedisin me përmbajtjen e ricikluar

- Përdorni kontejnerët e ripërdorshëm, mbajeni ose mbështesni shërbimet që mbledhin ambalazhimin e përdorur dhe riciklojnë atë.

\subsection{ROLET KRYESORE TE AMBALAZHIMIT}

Ambalazhimet e ushqimeve kanë rolin kryesor për të mbrojtur produktet ushqimore nga kontaminimi, dëmtimet dhe ndikimet e jashtme, për të kontrolluar ushqimin deri në konsumin e tij dhe ndihmojnë në mbajtjen e ushqimit freskët, por gjithashtu të përmbushin edhe kërkesa të tjera, duke siguruar konsumatorët me informacion mbi përbërësit dhe vlerat ushqyese.

Për të ruajtur sigurine ushqimore, ambalazhimet e ushqimeve: nuk duhet te tranferojnë përbërësit e tyre për në ushqim në sasinë e cila kalon limitet e përcaktura nga legjislacioni dhe në sasinë e cila rrezikon shëndetin e konsumatorit.

Qëllim tjetër i ambalazhimit të ushqimit është që të mbaj ushqimin në një mënyrë me kostoefektive që kënaq kërkesat e industrisë dhe dëshirat e konsumatorëve, duke mbajtur sigurinë ushqimore dhe minimizuar ndikimin në mjedis. 


\subsection{Cfarë duhet të kemi parasysh para zgjedhjes së ambalazhimit?}

\section{GJËRA QË DUHET TË KENI PARASYSH KUR ZGJEDHNI NJË KOMPANI PËR SHTYP TË AMBALAZHEVE TË USHQIMIT!}

1.Kostoja

e ambalazhës

Gjëja e parë dhe më e rëndësishme që duhet të keni parasysh është kostoja e ambalazhës.Prodhuesit e ushqimit në përgjithësi duan të kursejnë paratë në ambalazhe për të ofruar produkte me kosto sa më të ulët për konsumatorët. Kjo ka kuptim, pasi një produkt i kushtueshëm ka më pak gjasa të mbijetojë në tregun e konsumit.

2.Kujdesi i ushqimit ndaj ambientit të jashtëm Një faktor thelbësor i ambalazheve të ushqimit është rezistenca ndaj ambientit të jashtë. Ju duhet të kërkoni për një kompani që ju ofron shtyp kualitativ dhe me folie të ndryshme e cila mbron ushqimin apo produktin tuaj nga ambienti i jashtëm.

3.Etiketim në ambalazhë

Nëse ambalazhi i produktit tuaj të ushqimit është në material tjetër dhe jo në letër atëherë ju keni një mundësi zgjedhje për të shtypur etiketa vetëngjitëse për këto ambalazhe të ushqimeve tuaja. Këto etiketa mund të ofrohen në madhësi dhe dimensione të ndyshme.

\section{$\begin{array}{lllll}\text { 4.Porosi } & \text { e } & \text { shpejtë } & \text { e } & \text { ambalazheve }\end{array}$}

Për të siguruar që ofrimi i produktit tuaj të vazhdojë me ritmin e kërkesës së tregut. Ju duhet të konsideroni një kompani që siguron që produktet tuaja respektivisht ambalazhet për ushqimet tuaja do të jenë të gatshme varësisht kërkesave tuaja.

5.Cilësia materialit e ambalazhues

Kur zgjedh një kompani të ambalazhimit të ushqimit, një gjë që duhet të mendoni se duhet të kërkoni kompaninë që ju siguron mbështetje cilësore dhe inxhinierike që nga faza fillestare e projektimit deri te komercializimi i produktit.

\section{Kreativiteti}

dhe inovacioni Inovacioni është çelësi i një biznesi të suksesshëm. Ju duhet të kërkoni një kompani që ofron 
dizajnin tuaj të ambalazhës me kreativitet dhe inovacion. Duhet të jetë në gjendje të sjellë kreativitetin në produktin tuaj pa e ngritur koston e produktit.

\section{Angazhimi i kompanisë për të mbajtur marrëdhënien afatgjatë të biznesit me ju} Kompania juaj potenciale e ambalazhimit duhet të besojë në ruajtjen e marrëdhënieve afatgjata të klientëve, e cila bazohet në mirëkuptimin dhe besimin reciprok. Duhet të jeni të vetëdijshëm se si të fitoni këtë mirëkuptim dhe besim. Me një kompani të paketimit të drejtë, ju mund të shijoni situatën e fitimit dhe kënaqësinë në të dy anët.

Përfundimisht, niveli e rritjes së popullsisë lidhet drejtpërdrejt me zhvillimin e industrisë

ushqimore. Ai siguron që çdo konsumator i shtuar të kontribuojë në tregun e ushqimit. Industria ushqimore hap një treg të madh për ambalazhimin e ushqimit në Ballkan dhe Evropë. 


\section{SHQYRTIMI I LITERATURES}

\subsection{FUNKSIONET E AMBALAZHIMIT}

Funksionet themelore të produkteve ushqimore të ambalazhimit janë mbrojtja e ushqimit nga ndikimi i faktorëve të përkeqësimit, kontamimin, dëmtimet, ndikimet e jashtme, për të kontrolluar ushqimin deri në konsumimin e tij dhe ndihmojn në mbajtjen e ushqimit të freskët, por gjithashtu të përmbushin edhe kërkesa të tjera, duke siguruar konsumatorët me informacion mbi përbërësit dhe vlerat ushqyese.Për të ruajtur sigurinë ushqimore, ambalazhimet e ushqimeve: nuk duhet të transferojnë përbërësit e tyre për në ushqim në sasi e cila kalon limitet e përcaktuara nga legjislacioni dhe në sasinë e cila e rrezikon shëndetin e konsumatorit (Mane, 2011; Robertson, 2010).

\subsubsection{FUNKSIONI MBROJTES}

Funksioni i mbrojtjës i paketimit i referohet mbrojtjës së cilësisë së produktit nga të gjithë faktorët e dëmshëm në të gjitha fazat nga paketimi në konsumimin përfundimtar. Shkalla e degradimit së produktit është në funskion të faktorëve të përbërjes dhe procesit të përpunimit të ushqimit dhe faktorëve të mjedisit dhe shpërndarjes.

Faktorët e përbërjes dhe procesit të prishjes janë: aktiviteti i ujit, vlera e $\mathrm{pH}$, natyra e mikroflorës dhe numri i mokroorganizmave të mbijetuara në produktin përfundimtar, potenciali i redoksit, natyra kimike \biokimike e produktit, shtesat e shtuara, formulimet e produktit dhe ndërveprimet e paketimeve.

Faktorët mjedisor dhe faktorët e shpërndarjes janë: koha, temperatura, lagështia relative, drita përbërja e atmosferës së gazit. Për paketimin, mikroorganizamat, insektet dhe trajtimi I produktit. Përderisa ushqimi i pa ambalazhuar ka një humbje relativisht të shpejtë të cilësisë, ambalazhi e mban cilësinë e e ushqimit të paketuar në nivelin më të lartë të mundshëm sa me gjatë që është e mundur.

Shtrija e reagimimeve kimike varet nga: disponueshmëria dhe përqendrimi i reagjentëve, temperatura, drita dhe lagështia. Mbrojtja qe ambalazhimi siguron që në ushqimin e paketuar të parandalon ndryshimet e përbërjes të shkaktuar nga faktorët e mjedisit, si gazrat, lagështia ose drita. 
Oksigjeni është shumë reaktiv dhe potencialisht i rrezikshëm për llojet e shumta të ushqimit, pasi ajo shkakton reaksione kimike të padeshiruara të tilla si oksidimi në ushqim për të ndryshuar vetitë ushqyese dhe ndijore të ushqimit. Oksigjeni stimulon zhvillimin e mikroorganizmave aerobe që mund të shaktojnë prishje të ushqimit. Në këtë rast materialet e ambalazhimit duhet të kenë një penges të lartë ndaj oksigjenit.

Ka raste kur prania e oksigjenit eshte e dëshirueshme, siq janë proceset e fermentimit aerobe, ku prania e oksigjenit lejon zhvillimin e mikroorganizmave për të shtuar kulturën dhe për të parandaluar rriojen e mikroorganizmave anaerobe të padëshirueshme. Ambalazhimi për këto raste duhet të ketë i përshkueshmërinë adekuate të oksigjenit.

Ushqimet me një përmbajtje relativisht të lartë lagështie në lidhje me lagështin e ekuilibrit të produktit kanë tendencë të humbasin ujin ne atmosferë. Kjo qon në humbjen e masës dhe të strukturës, si dhe përkeqësimin e shfaqjesldukjes së ushqimit.

Produktet me përmbajtje lagështie nën lagështinë e ekuilibrit do të thithin lagështi nga atmosfera, sidomos kur ekspozohen ndaj lagështisë së lartë.

Nëse aktiviteti i ujit rritetmbi nivelin kritik, ai gjithashtu mund të qojë ne degradimin e ushqimit mikrobik. Në raste të tilla kërkohet ambalazhimi me përshkueshmëri të ulët të avujve dhe me mbyllje efektive.

Shumë përbërës të ushqimit janë të ndjeshem ndaj ndritës. Nën ndikimin e dritës, yndyra keqësohet, ngjyra e ushqimit zbehet dhe vitaminat mund të shaktërrohen. Për ushqim me përbërës të tillë, si zgjidhje është një ambalazhim rezistent ndaj dritës, edhe psë ndonjëherë kjo shkon në dëm të dëshirës së konsumatroit për te parë ushqimin e ambalazhuar dhe vlerësimin e vetive vizuale para se të blejë atë.

Mbrojtja biologjike i referohet barrierës ndaj mikroorganizmave, insekteve dhe kërpudhave. Përveq kësaj, barrierat bilogjike sigurojnë kushtet për kontrollin e vjetërimit. Barriera të tilla punojnë nëpërmjet një numri mekanizmash, duke përfshirë: prandalimin e qasjes në ushqim, parandalimin e transmetimit të aromës dhe ruajtjen e atmosferës së brendshme të ambalazhit. Ambalazhimi nuk duhet të dëmtojë cilësinë e ushqimit. Duhet të jetë jo toksik për ushqim. Veqanërisht, pyetja është "migrimi normal", d.m.th transferimin e përbërësve nga paketimi i ushqimit. 
Kërkesat e ambalazhimit që lidhen me ambalazhimin kanë të bëjnë me integritetin e ambalazhës, duke përfshirë formimin, mbushjen dhe mbylljen e ambalazhimit. Kapaku, elementet e tjera të mbyljes jo adekuate, nuk do të japin rezultate të vërteta mbrojtjeje.

\subsubsection{FUNKSIONE INFORMATIVE}

Ambalazhimi është një nga mjetet më të rëndësishme të komunikimit dhe marketingut nga ana e prodhuesit tek konsumatori, nëpërmjet të cilit transmetohen informacione të caktuara.Ambalazhimi primar duhet që konsumatorit potencial ti ofrojë një gamë informacioni përmes elementeve vizulale dhe informative që të ndikojnë në vendimin e blerjes së tij.Elementet vizuele përbëhen nga grafika dhe madhësia ose forma e ambalazhmit dhe luajnë një rol thelbësor në identifikimin, paraqitjen dhe promovimin e produkteve tek konsumatorët, duke e bërë produktin të dallueshem dhe të adaptueshëm.

Elementet e informacionit lidhen me informacionin mbi teknologjitë e përdorura në prodhim dhe ambalazhim, dhe për vet produktin, të tilla si: përbërja, kohëzgjatja, përdorimi dhe mirëmbajtja, dhe aspekte të tjera informuese që ndikojnë në vendimin e blejres. Këto elemente janë: letra, tekste, etika dhe numra.Paketimet e mëdha kryesisht i ofrojnë shitësit dhe blerësit llojin e informacionit si: numrin e produkteve të ambalazhuar në njësi, masat, llojin e produkteve dhe nganjëherë informacionin mbi ofertat $20 \%$ falas.

Informacioni mbi paketimin për transport është kryesisht për shpërndarësit dhe punëtorët e magazinimit.

\subsubsection{FUNKSIONE TE DOBISHME}

Funksionet e dobishme të ambalazhimit i referohen trajtimit të lehtë të produktit, hapjen e lehtë të ambalazhimit, përgaditjen e produkteve për përdorim, mundësinë për të marrë një sasi të kërkuar të ushqimit, dukshmërinë e ushqimit dhe ri-mbyllje të lehtë, si dhe përdorimi i mundshëm i ambalazhimit të zbrazur.

Në këtë kuptim, ambalazhimi duhet të dizajnohet në mënyrë qe forma e tij të jetë egronomikisht dhe funksionalisht më i përshtatshëm dhe më i pranueshëm për konsumatorët.Konsumatorët po kërkojnë gjithnjë e më shumë ambalazhime te cilat happen lehtësisht në sajë të shpimeve të ndryshme, ambalazhime të përshtatshme për konsumin e ushqimit në lëvizje, ambalazhime me priza për dozim etj. 


\subsubsection{FUNKSIONI I PERMBAJTJES}

Funksioni i përmbatjës i referohet aftësisë së ambalazhimit për të mbajtur ushqime të natyrës dhe formave të ndryshme fizike, në kushte të ndryshme mjedisore dhe për të parandaluar humbjen e përmbajtjes në masë.

Format e ndryshme të ushqimit ndikojnë në përzgjedhje e materialeve dhe formave të ambalazhimit. Materiali duhet të jetë i qëndrueshëm sipas vetive kimike, termike dhe mekanike të ushqimit.

\subsubsection{FUNKSIONI I SIGURISE}

Funksioni i sigurisë së ambalazhimit është rezultat i përpjekjeve gjithnjë e më intensive për të rritur sigurinë e konsumatorit. Qëllimi i funksionit të sigurisë është zvogëlimi i rrezikut të hapjes së paautorizuar të produktit në mënyrë të tillë që, së pari, eliminoon mundësinë e hapjes së paautorizuar dhe tjetri identifikon prduktin tashmë të hapur në raft.

Kapakët prej alumini dhe plastike në kavanoza gjithashtu mund të ndihmojë konsumatorët të identifikojnë hapjen e mëparshme të paautorizuar.Rritja e kërkesave të konsumatorëve për siguri më të madhe të produkteve dhe hapja e paautorizuar ka sjellë kohët e fundit novacionet e paketimit qe kontribojnë në besimin edhe më të madh të konsumatorit.

\subsubsection{FUNKSIONI I AMBALAZHIMIT EKOLOGJIK}

Funksioni i ambalazhimit ekologjik është një funksion më i ri.Detyra kryesore e ambalazhimit është mbrojtja e ushqimit në të gjitha fazat nga toka në tavolinë për të zvogëluar mbetjet ushqimore dhe mbeturinat ushqimore, pasi deri në 50\% të ushqimit të prodhuar nuk arrin në tavolinë. Funksioni ekologjik i ambalazhimit i referohet përdorimit të ambalazhimit miqësor me mjedisin (eco friendly). Është një ambalazhim i bërë nga materialet e biodegradueshme që edhe kur përfundohen si një paketim i deponuar, nuk kanë ndikim negative në mjedis ose ndikimi është minimal për shkak të biodegradueshmërisë së tyre. 


\section{DEKLARIMI I PLOBLEMIT}

\subsection{ETIKETIMI DHE DIZAJNIMI I USHQIMIT}

Etiketa e një produkti ushqimor duhet të përmbajë patjetër disa të dhëna të cilat cilësohen të detyrueshme, sikurse janë: emri i produktit, lista e përbërësve të produktit dhe sasia e përbërësve të veçantë, afati i përdorimit ose i skadencës, kushte të veçanta të ruajtjes dhe të përdorimit, deklarimin e sasisë neto, adresa e prodhuesit ose ambalazhuesit, vendi i origjinës ose prejardhjes së produkteve ushqimore në mënyrë që mos të keqinformojë konsumatorin, udhëzime të përdorimit për produktet që në mungesë të këtyre udhëzimeve është i pamundur përdorimi i tyre, gradën alkoolike për pijet që përmbajnë më shumë se $1.2 \%$ të volumit alkool.

Po kështu etiketa e produkteve ushqimore mund të përmbajë dhe informacion mbi vlerat ushqimore që lidhen me: vlerën energjetike, ushqyesit, proteina, karbohidrate, yndyrë, fibra, sodë, vitamina dhe kripëra minerale, si dhe deklaratat nutritive (ushqimore) që nënkupton çdo mesazh që tregon, sugjeron që një ushqim ka veti të veçanta dhe të dobishme ushqyese.

Ekzistojnë 10 kërkesa ligjore për etikimin e ambalazhimit të ushqimit:

1. Emri i produktit

2. Përshkrimi i produtit

3. Emir dhe adresa e prodhuesit

4. Pesha apo vëllimi i produktit

5. Këshilla për alergji

6. Vendi i origjinës

7. Lista e përbërësve

8. Shënimi i të dhënave

9. Udhëzime për përdorim

10. Udhëzime për ruajtje

Dizajni është një aktivitet shkencor, professional dhe krijues që përfshin teknikë, teknologji, informatikë, estetikë, aplikim dhe art visual, ekonomi, psikolgji, ergonomi dhe organizim. Dizajni i paketimit ka ndikim të madh në vendimin për blerje te produktit, si psh:

Ngjyra që është një elment i rëndësishëm në krijimin e nje strategjie marketingu për prouktet. Përmes ngjyrës transmetohen informacione të tilla si kategroia, shija, origjina dhe vetitë specifike të produktit.Forma dhe madhësia janë faktorë të rëndësishëm në cilësinë estetike, teknikefunksionale, ekonomike dhe ergonomike të produktit. 
Pamja-fotografia, vizatimet e stilizuara, ilustrimet, në mënyrë të ngjajshme dërgojnë mesazhe të caktuara konsumatorëve dhe u shkaktojnë disa efekte emocionale.

Fjalët dhe numrat në ambalazhim, konsumatorëve u dergohen mesazhe shumë specifike dhe infromacione lidhur me produktet qe ndikojnë te blerësit për arsyeshmërinë e vendimit për blerje. 


\section{METODOLOGJIA E HULUMTIMIT}

\subsection{QELLIMI I HULUMTIMIT}

Qëllimi i këtij hulumtimi do të jetë drejtuar nga rëndësia e ambalazhimit, gjendja e ambalazhimit në Kosovë. Përkundër rëndësisë së paketimit të industrive ushqimore, ajo është mjaft anonime dhe është lënë pas dore disi në përpjekjet e kërkimit të marketingut në Kosovë. Qëllimi i këtij studimi ishte të shqyrtojë lidhjen midis ambalazhimit dhe sjelljes së konsumatorëve të produkteve ushqimore në Kosovës si dhe në qëllimin e hulumtimit duhet të zbulohet se sa janë të informuar qytetaret per ambalazhimin dhe se sa rëndesi ka ambalazhimi.

\subsection{OBJEKTIVAT E HULUMTIMIT}

Për të arritur qëllimin e hulumtimit kemi zgjedhur disa detyra:

- Të analizojmë dhe të studiojmë këtë problem;

- Të hartojmë anketën (pyetësorin), si mjet hulumtimi;

- Të informohemi nga qytetarët;

- Të grumbullojmë të dhëna përmes pyetësorëve;

- Të bisedojmë me palët e interesit.

\subsection{DETYRAT E HULUMTIMIT}

Për të bërë ndricimin e kësaj dukurie ne duhet të kryejmë disa detyra prej të cilave do të vecojmë:

- Të analizojmë dhe studijojm përmbajtjet dhe të arriturat teorike ne lidhje me ambalazhimin dhe rendesin e tij tek qytetaret;

- Të organizohet veprimtaria kërkimore në sistemin e aplikimit të instrumenteve si mjete të hulumitimit për grumbullimin e opinionit mbi temen në fjalë;

- Prezantimi dhe paraqitja grafike e të dhënave

- Interpretimi i rezultateve te hulumtimit 


\subsection{METODAT,TEKNIKAT DHE INSTRUMENTET E HULUMTIMIT}

Si metodë më të përshtatshme gjatë hulumtimit është aplikuar metoda e analizes teorike, inductivededuktive, observativo-deskriptuese, statistikore si dhe metoda e bisedës.

Si teknika të hulumtimit janë përdorur: anketimi, ndersa si instrumente janë përdorur: pyetësori. Të gjitha analizat statistikore janë punuar duke përdorur programi MS Excel.

\subsubsection{MOSTRA E HULUMTIMIT (POPULLACIONI)}

Popullacioni dhe mostra

Zhvillimi i hulumtimit është kryer në qytetin e Prishtinës në Kosovë.

Popullacioni i këtij hulumtimi janë qytetarët e Repubilkës së Kosovës, në komunën e Prishtinës. Mostra e këtij hulumtimi është numerikisht e pacaktuar.

\subsubsection{Pyetësori}

1.A i preferoni ambalazhet e letrës apo plastikës?

2.Gjendja e ambalazheve në Kosovë?

3.A mendoni se plastika është e dëmshme për shëndetin?

4.Çka ju tërheqë më shumë tek ambalazhi I një produkti?

5.A mendoni se duhet larguar qeset e plastikës?

6.Sa ndikon çmimi në përzgjedhjen e produkteve?

7.Gjatë përzgjedhjes së produktit ushqimor, a ndikon lloji i materialit me të cilin është ambalazhuar?

8.A jeni të gatshëm të paguani një shtresë për ambalazh më të sigurtë?

9.Çfarë informacioni mendoni se është I rëndësishëm të vendoset në etiketë?

10.A e dini dallimin në mes: best to uised before...dhe expiration date?

11.A ndikon dizajni i ambalazhimit tek blerja e një produkti? 


\section{PREZANTIMI DHE ANALIZA E REZULTATEVE}

1. A i preferoni ambalazhimet e letres apo të plastikes?

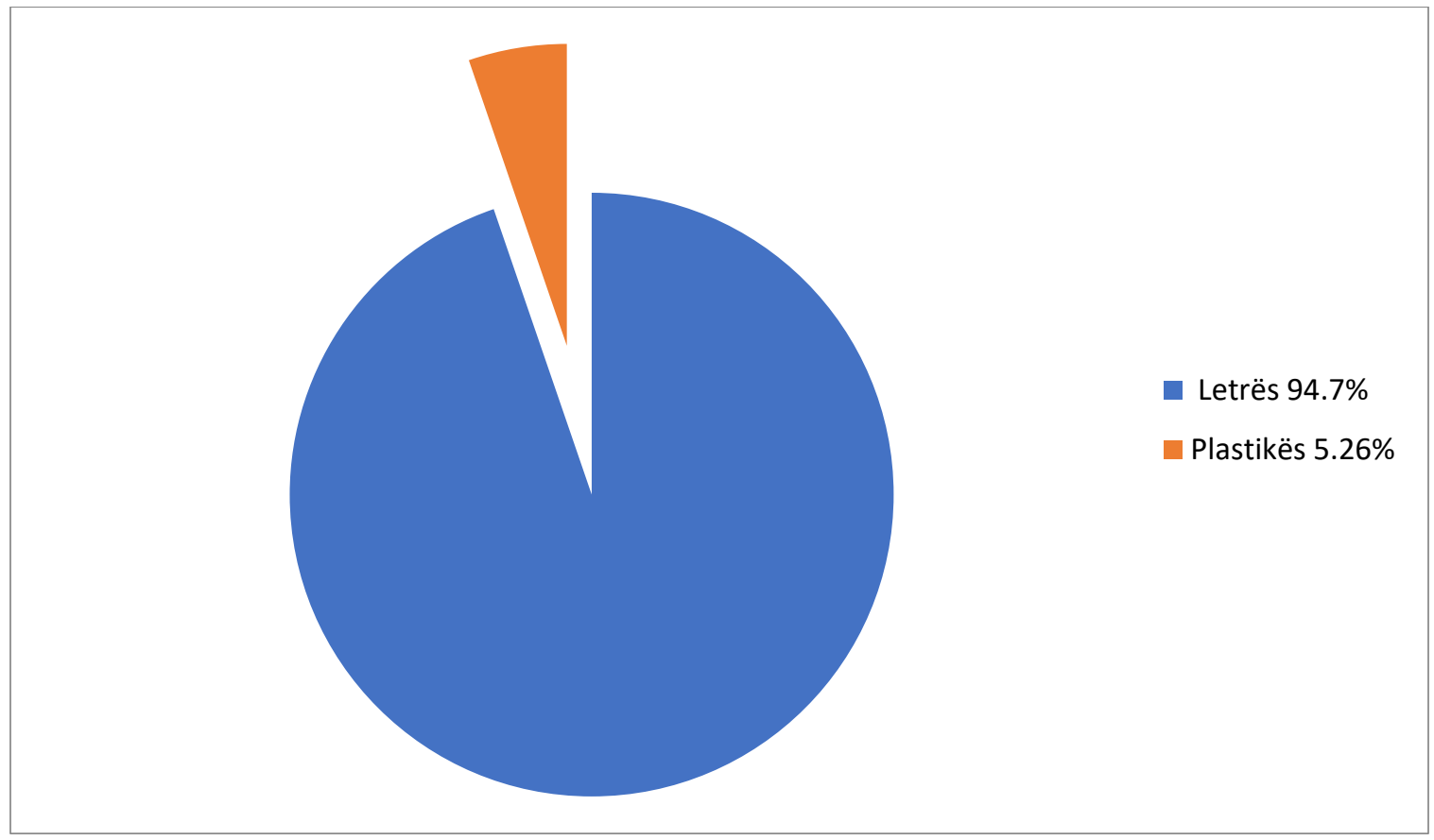

2.Gjendja e ambalazheve në Kosovë? 


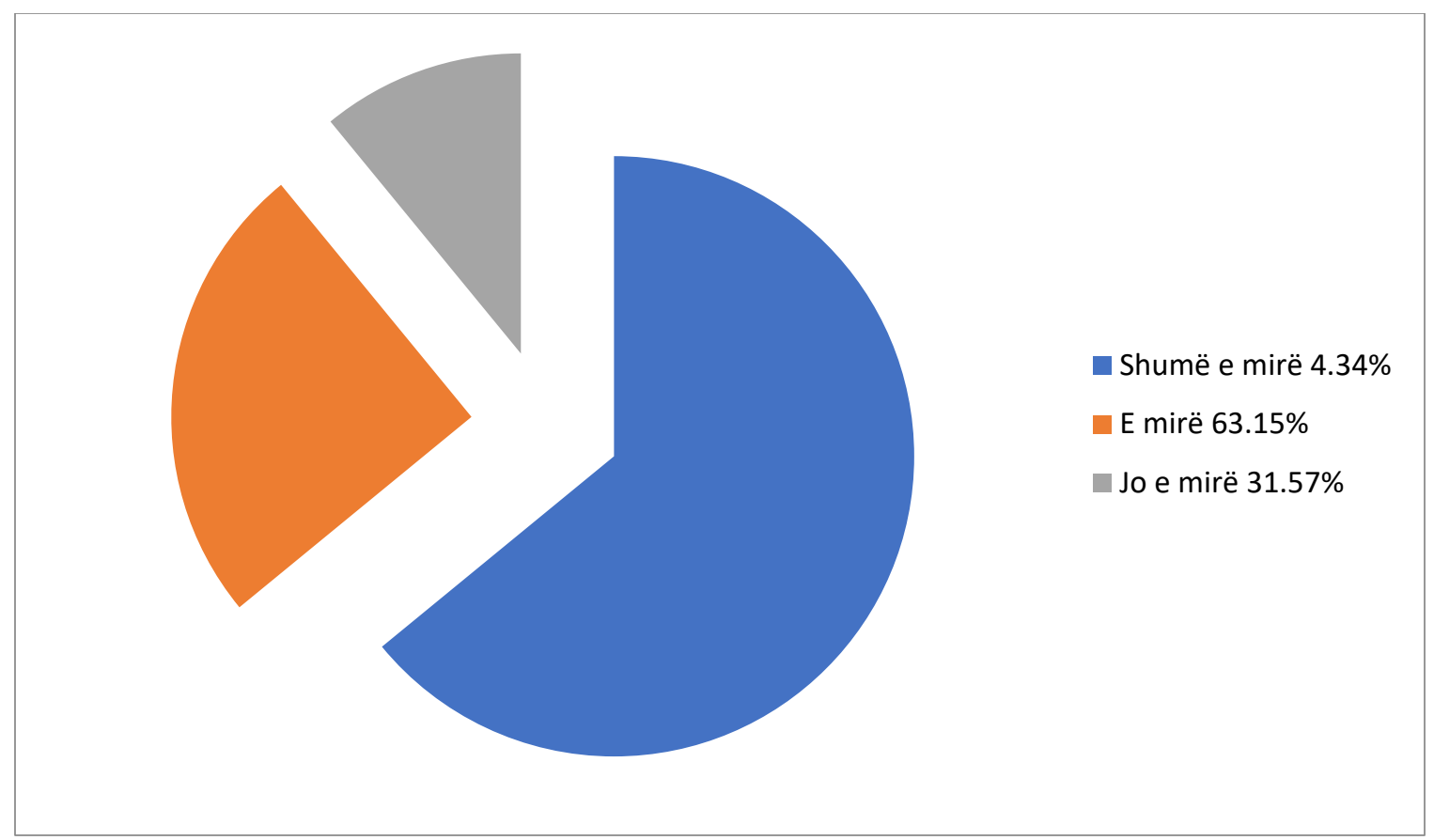

3.A mendoni se plastika është e dëmshme për shëndetin?

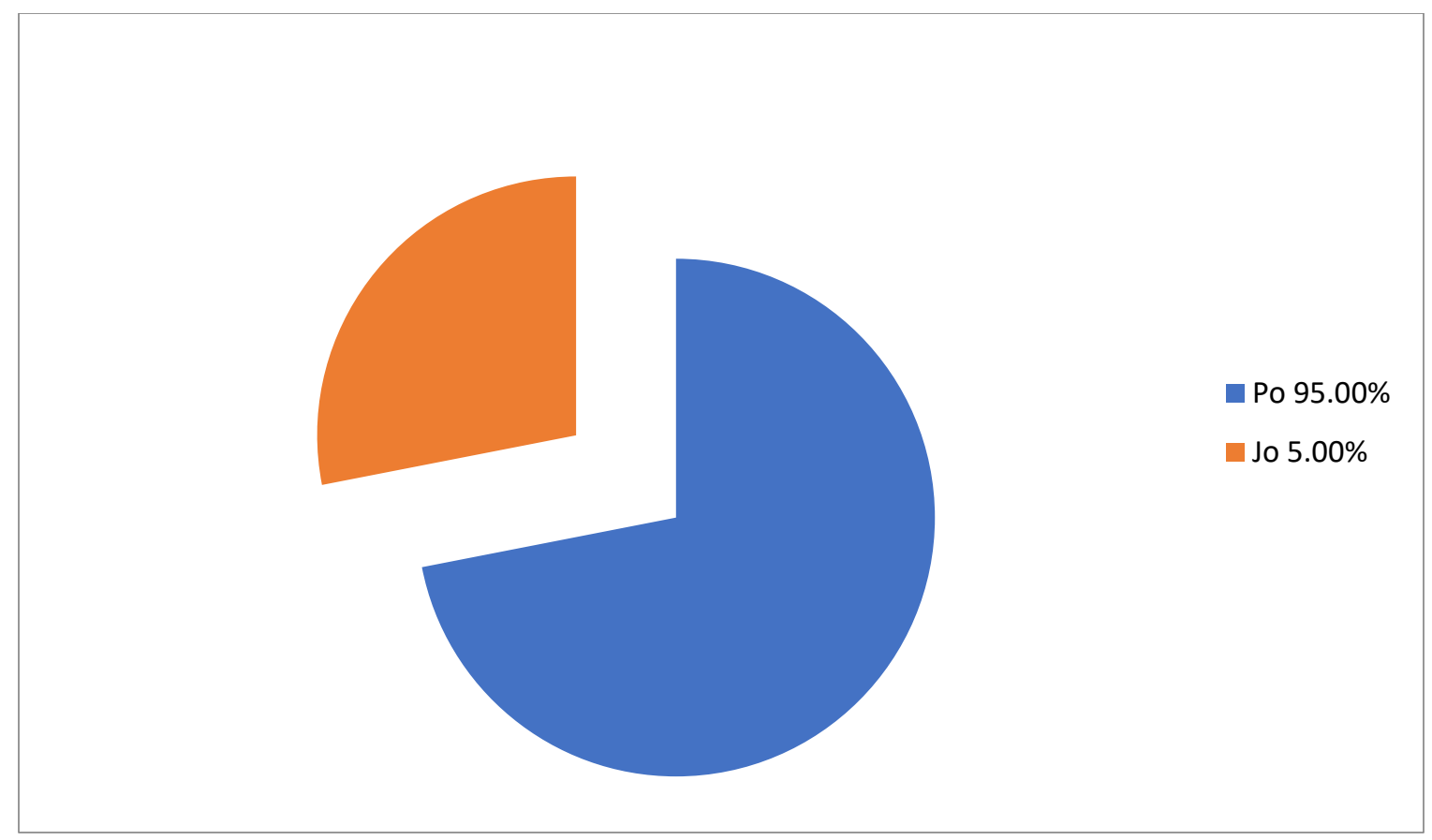

4.Çka ju tërheqë më shumë vëmendje tek ambalazhi i një produkti? 


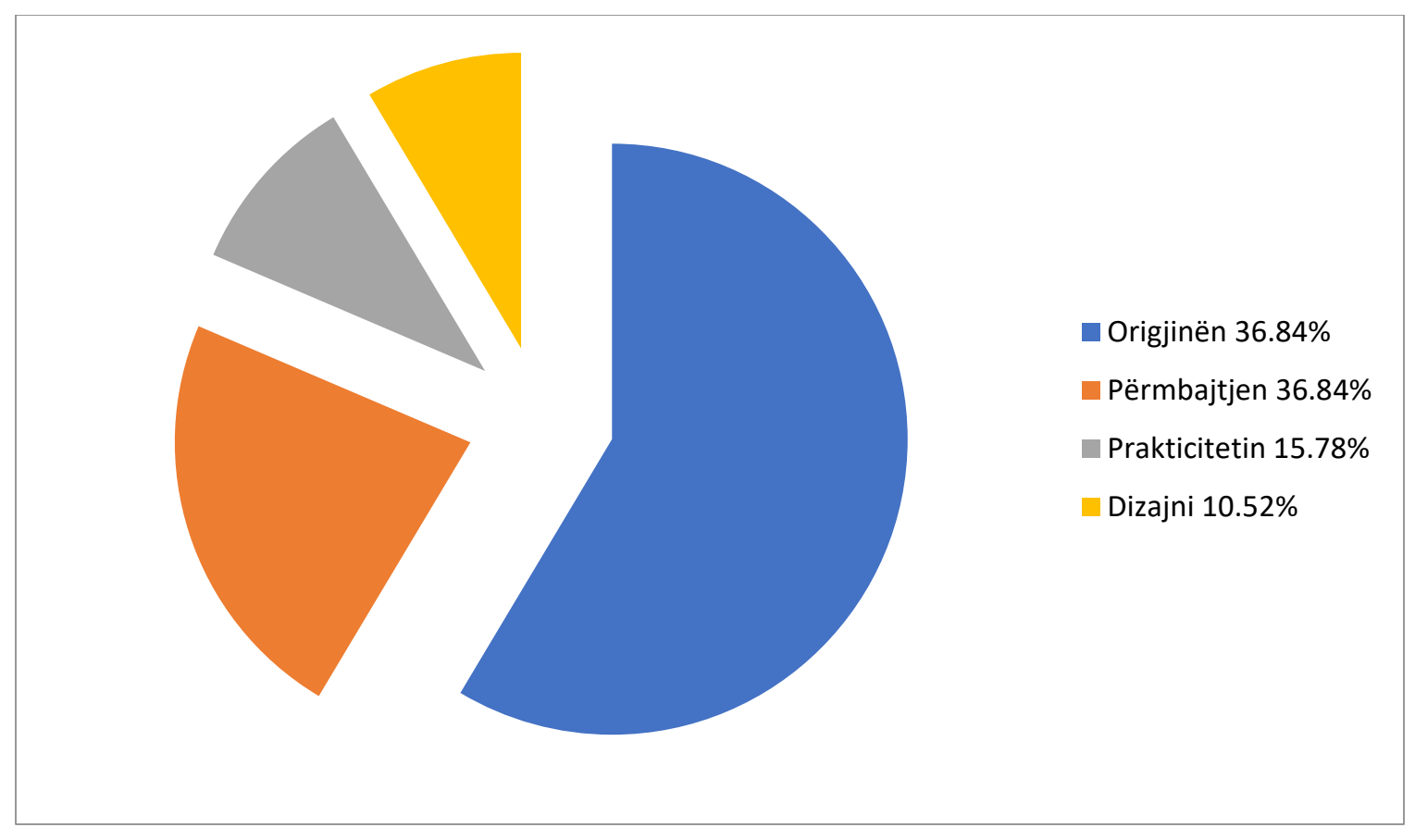

5. A mendoni se duhet larguar qeset e plastikës ?

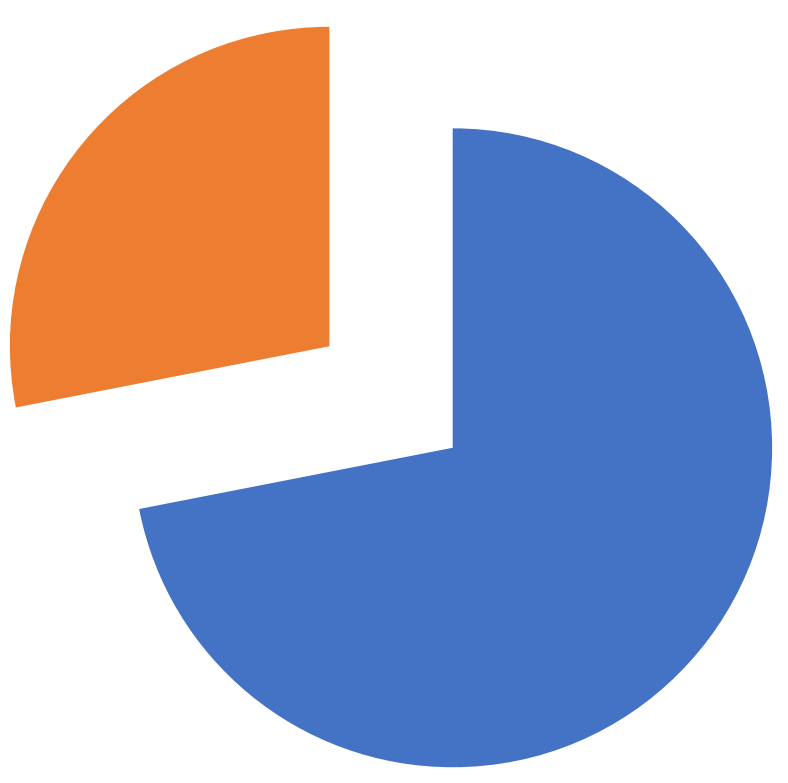

- Po $84.21 \%$

Jo $15.78 \%$ 
6.Sa ndikon çmimi në përzgjedhjen e produkteve?

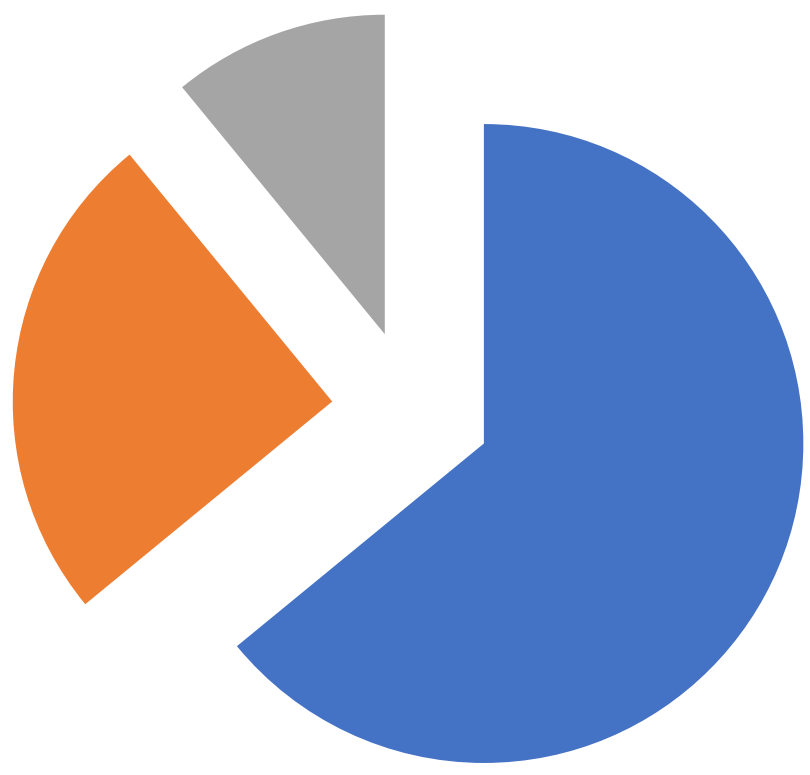

- Shumë $47.36 \%$

Mesatarisht $47.36 \%$

Nuk ndikon $5.57 \%$

7. Gjatë përzgjedhjes së produktit ushqimor, a ndikon lloji i materialit me të cilin është ambalazhuar?

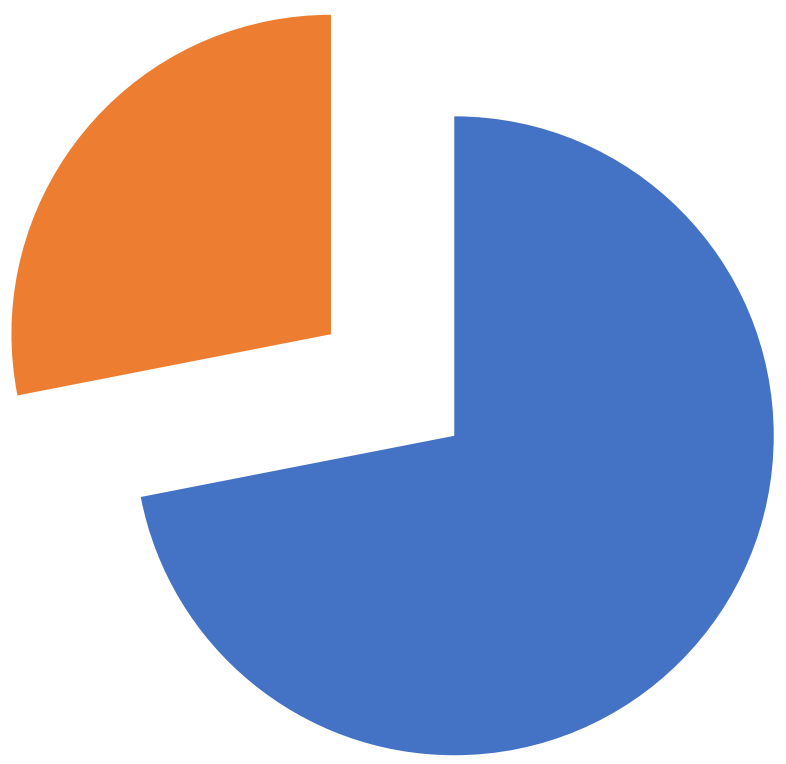

Ndikon $63.15 \%$

Nuk ndikon $36.84 \%$ 
8.A jeni të gatshëm të paguani një shtresë për ambalazh më të sigurt?

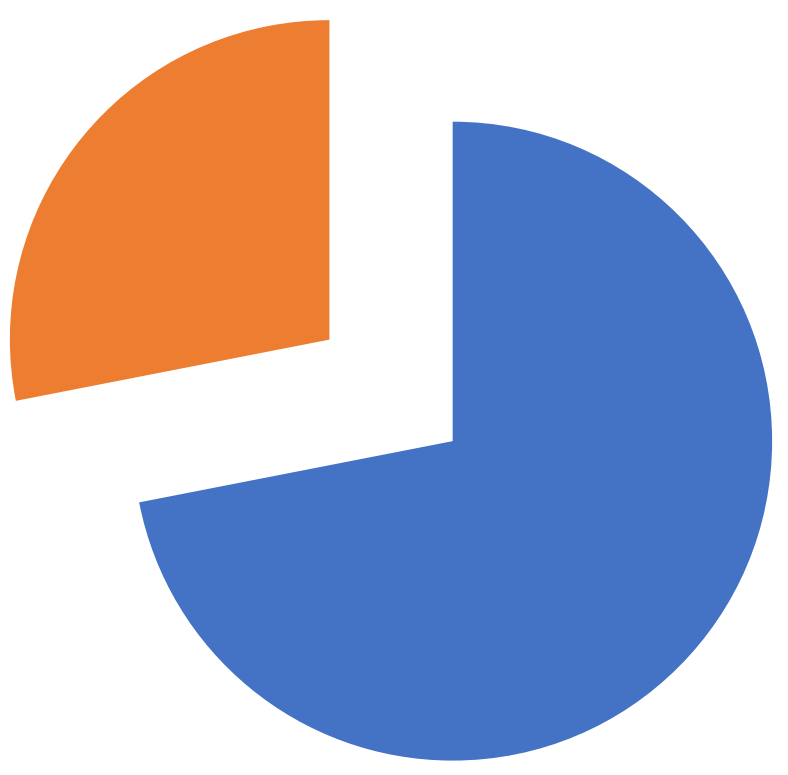

9.Çfarë informacioni mendoni se është më i rëndësishëm të vendoset në etiketë?

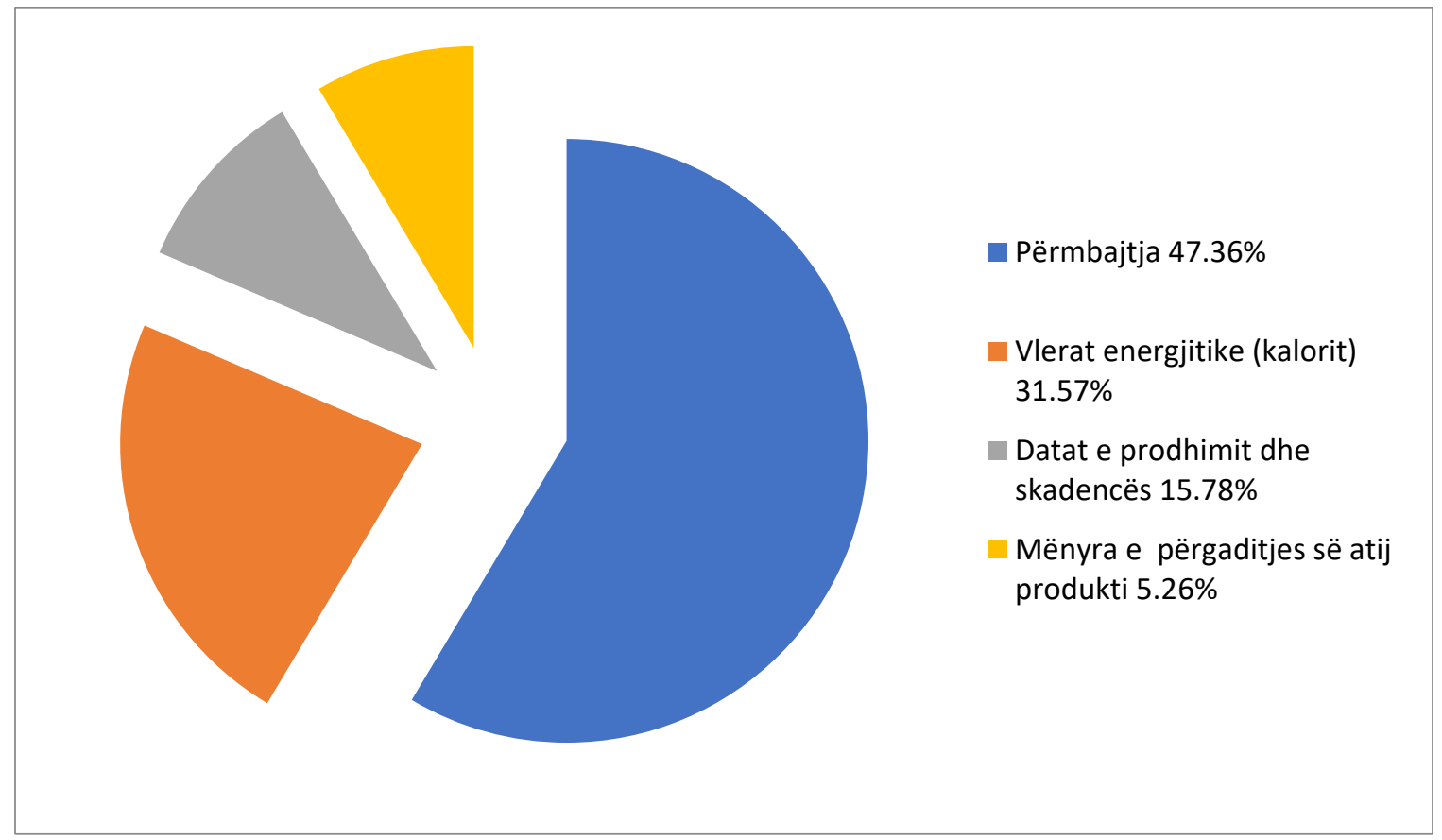


10.A e dini dallimin në mes: best to used before..... dhe expiration date.....?

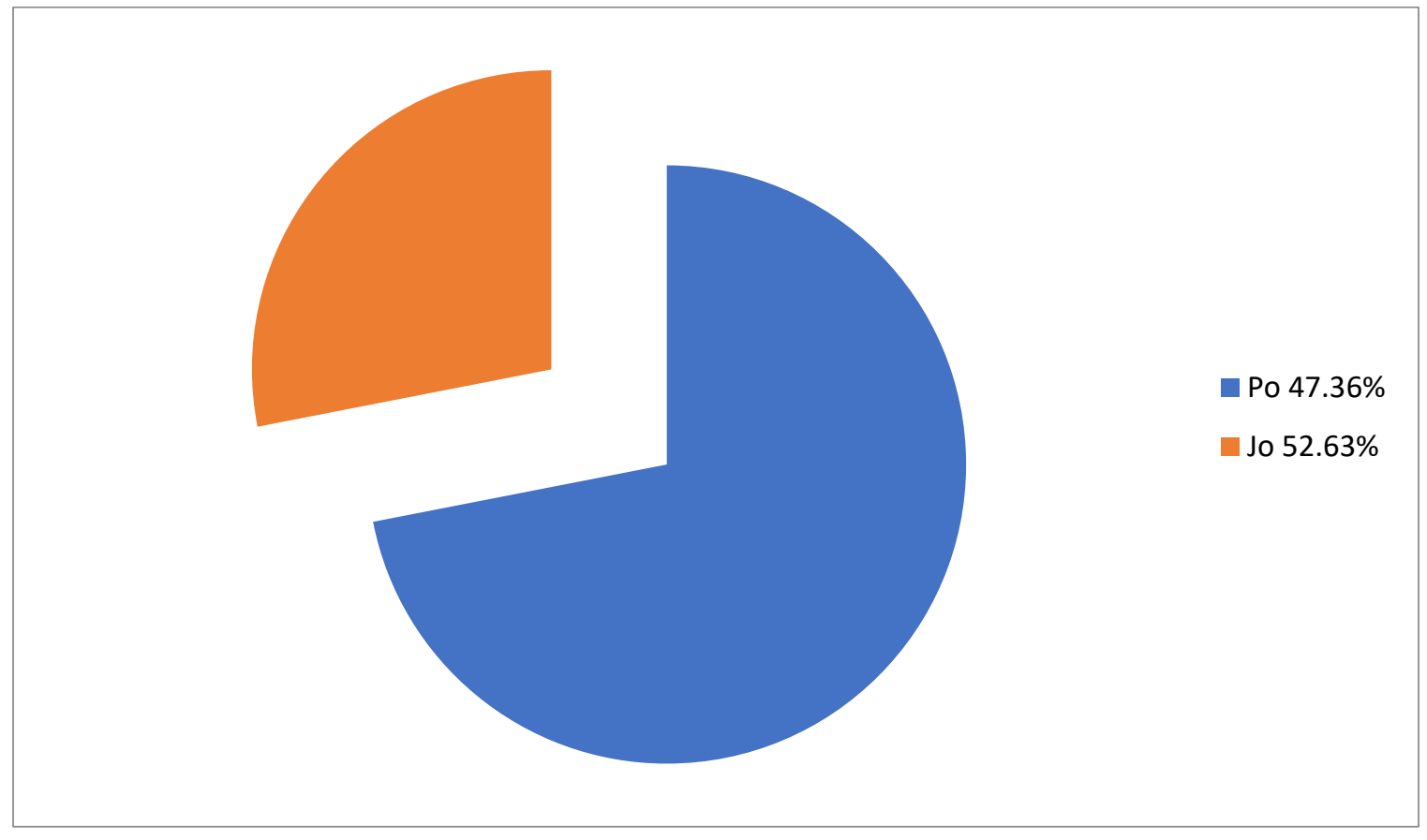

11.A ndikon dizajni ambalazhimit tek blerja e një produkti?

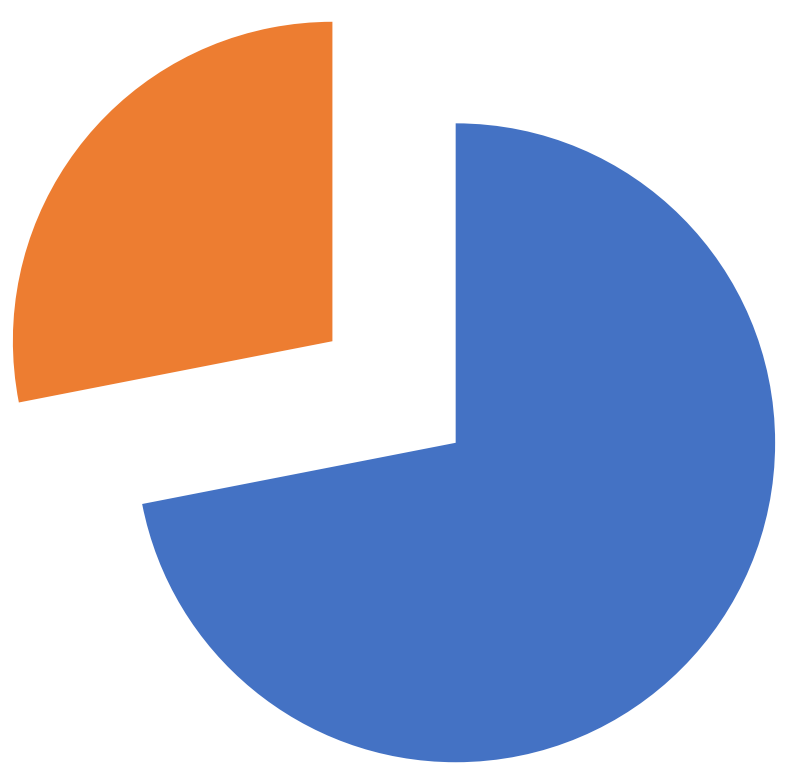

Po $53.67 \%$

Jo $46.33 \%$ 


\section{KONKLUZIONE DHE REKOMANDIME}

Nga tërë kjo që u tha më parë, pamë se ambalazhimi luan rol tek konsumatrët. Bazuar në kërkimin tonë shihet se qytetaret janë të pajtimit që plastika është ë dëmshmë por vazhdojnë ende ta përdorin për shkak të mungesës se letrës, por edhe shkaku i kostos.

Të gjitha të dhënat e poshtëshënuara, vërtetojnë hipotezën themelore ose kryesore, të cilat pasqyrojnë gjendjen e tanishme te ambalazhit dhe ndryshimet të cilat duhet të bëhen.

- Aplikimi i observimit si metodë më e shpeshtë për identifikimin apo zbulimin e mendimit të qytetarve rreth ambalazhit dhe rëndësis së tijë.

- Mungesa e informacionit te qytetarët është ë madhe për shkak mos informimit nga mediat dhe organet e caktuara.

- Mungesa e informimit dhe orinetimit të vazhdueshëm professional;

- Mungesa dhe mos aplikimi i risive dhe teknologjive të reja:

Prandaj është e nevojshme të merren këto masa:

1. Në shkolla te informohen nxënësit rreth ambalazhit:

2. Të informohen qytetarët në mëdia:

3. Të informohen rreth plastikës dhe pasojat apo dëmet që shkakton ajo:

4. Të dijnë të bëjnë dallimin midis ambalazhimit dhe paketimit:

5. Që plastika të zëvendësohet me letër në produkte që ka zgjidhje:

6. Të produkti të shikohet edhe origjina:

7. Higjiena e ambalazhimit:

8. Kontrrollimi i skadencës tek produktet e ambalazhuara:

9. Transparenca rreth informacionit:

10. Cilësia e materialit ambalazhues:

11. Etiketimi në ambalazh. 


\section{REFERENCAT:}

1. Guillard V., Gaucel S., Fornaciari C., Angellier-Coussy H., Buche P. and Gontard N. (2018). The Next Generation of Sustainable Food Packaging to Preserve Our Environment in a Circular Economy Context. Front. Nutr. 5:121.

2. Raheem D. (2012). Application of plastics and paper as food packaging materials - An overview. Emir. J. Food Agric. 25 (3): 177-188.

3. Jiahui J., Zhang M., Bhandari B., Cao P. (2019). Current processing and packing technology for space foods: a review, Critical Reviews in Food Science and Nutrition.

4. Arvanitoyannis I.S., Bosnea L. (2004). Migration of substances from food packaging materials to foods. Crit Rev Food Sci Nutr 44(3): 63- 76.

5. Hotchkiss JJ. (1997). Food-packaging interactions influencing quality and safety. Food Addit Contam 14(6-7): 601-7.

6. Lau OW., Wong S.K. (2000). Contamination in food from packaging materials. J Chrom. A 882(1-2): 255-70.

7. Estiri M., Hasangholipour T., Yazdani H., Nejad H.J, Rayej H. (2010). Food Products Consumer Behaviors: The Role of Packaging Elements. Journal of Applied Sciences, 10: 535-543.

8. Eker B., Içöz A. (2016). PACKAGING MATERIALS AND EFFECTS ON QUALITY OF LIFE 1 st International conference on Quality of Life.

9. OUR FOOD PACKAGING \& PUBLIC HEALTH. (2012). Environmental Health Perspectives. $120(6)$.

10. Thackston E. (2013). "THE EFFECT OF PACKAGING MATERIAL PROPERTIES ON CONSUMER FOOD QUALITY PERCEPTION IN QUICK-SERVICE RESTAURANTS". All Theses. 1673.

11. Codex Alimentarius Commission. (2004). Report of the 20th session of the Codex committee on general principles. Joint FAO/WHO food standards programme. 2004 May 2-7. Paris, France $.44 \mathrm{p}$.

12. Eranda Mane (2011). Ruajtja dhe ambalazhimi i produkteve ushqimore. Tiranë.

13. Muhamedbegoviç B., Nils V. J., Jasiç M. (2015). Ambalazha i pakiranje hranje, Sarajevo.

14. Robertson L.G. (2010). Food Packaging and Shelf Life.By Taylor and Francis Group, LLC.

15. VUJKOVIĆ I., GALIĆ K., VEREŠ M. (2007). Ambalaža za pakiranje namirnica, Sveučilišni udžbenik, TECTUS, Zagreb. 
16. Karen A.B., Sinclair C.R., Watson D.H. (2007). Migration and Food Contact Materials, CRC Pres.

17. Rijk R., Veraart R. (2007). Global Legislation for Food Packaging Materials, Second Completely Revised Edition. 